\title{
The Expectation Of Top-Level Management Of The Capabilities And Efficiency Of Human Resource Executive Officers: A Case Study Of Local Administrative Organizations In Phetchabun Province, Thailand
}

Sombut Boonleaing, Phetchabun Rajabhat University, Thailand

\begin{abstract}
ABSTARCT
The objectives of this study are as follows: 1) to study the expectation of the capabilities and efficiencies of human resource executive officer at the top management level of local administrative organizations and 2) to explore the guidelines for the development of the capabilities and efficiencies of the human resource executive officers at local administrative organizations. This study uses both quantitative and qualitative methods. The study found that in every organization, the HR department has the same job descriptions, such as HR planning, wage and salary evaluation, handling complaints from employees, managing the welfare of and benefits for employees, job orientation, training and development, work data and statistical records, work assessment, writing job descriptions, consulting, managing the relationship between the employer and the employees, and the development of job efficiencies. The first hypothesis testing shows that the top management level at various-sized local administrative offices has the same expectations with respect to the characteristics of human resource executive officers. The second hypothesis testing shows that the top management level at various-sized local administrative offices have the same expectations with respect to the capabilities and efficiencies of human resource executive officers. Furthermore, according to the guidelines for the development of capabilities and efficiencies of human resource executive officers at local administrative organizations, the HR executive officer must act as follows: 1) know the business orientation; 2) act as a change agent; 3) have leadership; 4) act like an advocate; and 5) function as an HR expert.
\end{abstract}

Keywords: Local Administrative Organization, Human Resource, Efficiencies, Capabilities

\section{INTRODUCTION}

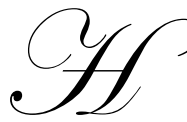

uman resources are the heart of an organization because humans are inventors, designers, financial resource controllers, and organizational administrators. Nonetheless, human resources cannot predict the future when compared with technology and financial resources. Moreover, organizations have to spend large amounts on human resource management. This is why this resource has to be managed well for the personal satisfaction and suitability of work needs to achieve the organization's goals (Keawying, 1991:4). Promsaka Na Sakolnakorn et al (2009) found that human resource management is the most significant issue that affects an organization. Lee and Hsin's (2004) study on human capital management reveals that human resource development typically faces obstacles. Providing knowledge and resources to laborers, such as training, will increase work efficiency and upgrade staff quality. 
Winotapan (2009) describes the problem of human resource management as follows. 1) Lack of attitude; the chief executive mostly focuses on departments that make more profits for the organization. They view human resources as merely a supporting unit for the organization. 2) Technology is constantly updated. The more information an organization has, the better chance it has to win in the market. 3) Human resource administrators do not realize the importance of human resources. 4) The staff are inefficient or do not try to improve themselves for the organization. In addition, the staff do not develop their skills, which hinders an organization's ability to compete with other organizations in the increasingly globalized market.

As I mentioned above, human resources produces skills and knowledge for the organization. The importance of human capital is the main factor in managing human resources in an organization. For example, each organization must have the board of administration select and design organizational plans and develop human resources in the organization because human resources help an organization compete by developing staff behavior. Furthermore, social capital causes change to human capital or makes plans for achieving organizational goals. This is why organizations must pay attention to human resources' many functions, such as maintaining quality staff and providing suitable salary and compensation to help organizations develop in the dynamic global market.

Human resources have an effect on organizational achievement. Human resource departments have become increasingly important as they take on a rising role in management and development. Consequently, human resource administrators have to increase employee efficiency, competency, and skills to reflect to their organization's policy. This research will focus on the expectations of chief executives for human resource administrators' roles and capabilities. It will explore chief executives' expectations of human resource administrators on developing human resource departments and finding the benefits of staff recruitment under organizational policies.

\section{OBJECTIVE}

1) To study the expectations of the capabilities and efficiency of human resource executive officers at the top management level of local administrative organizations.

2) To explore the guidelines for the development of the capabilities and efficiency of human resource executive officers at local administrative organizations.

\section{HYPOTHESIS}

1) Top-level management at various-sized local administrative offices has different expectations of human resource executive officers.

2) Top-level management at various-sized local administrative offices has different expectations with respect to the capabilities and efficiency of human resource executive officers.

\section{RESEARCH METHODOLOGY}

This paper uses both quantitative and qualitative methods. In the quantitative method, the researcher provided questionnaires for sampling. The sampling group in this study is top-level management, presidents and/or vice presidents, in 123 local administration organizations (LAO) in Petchabun province. In addition, the organizations are divided into 3 sizes, which are as follows: 1) large organizations, such as provincial administration organizations, district municipalities, and city municipalities; 2) middle organizations, such as sub-district municipalities; and 3) small organizations, such as sub-district administrative organizations.

The qualitative method used the focus-group process by inviting 5 experts to analyze the development of the capabilities and efficiency of human resources executive officers at local administrative organizations in Petchabun province.

\section{LOCAL ADMINISTRATIVE ORGANIZATION}

Decentralization in Thailand occurred in May 1992. The central government was considered one of the most significant measures in strengthening Thai democracy (Chareonmuan, 1997: 96-97). From 1994-1995, a new form of local-self government was set up, and the LOA was established in 1997 (Nelson, 2000: 34-35). In addition, 
this decentralization process aimed to transfer functional responsibilities to local governments to enhance local autonomy and discretion and to allow local communities to have a greater say in the management of public resources and in planning their own socio-economic development (Mutebi, 2004).

Local administration in Thailand is based on the concept of devolution, which allows local people to participate in the local government process under related laws and regulations. At present, there are two types of local administrative organizations in Thailand. The general type seen in every province is composed of the Provincial Administrative Organization (PAO), the municipality, and the Tambon Administrative Organization (TAO). The second type, special local government, is composed of the Bangkok Metropolitan Administration (BMA) and the City of Pattaya (Nagai, Mektrairat, \& Funatsu, 2008). There are 5 types of local administrative organizations in Thailand:

1) Provincial Administration Organizations (PAO) are the largest bodies in Thailand's provincial administration; each province has one, except Bangkok. The PAO is responsible for an entire province, set up with the aim to manage and provide public services within its province, helping municipal works and the sub-district administrations; it does so by collaborating with other administrations within the same province to avoid power redundancy and appropriate budget allocation.

2) Municipalities refer to provincial political units, such as a city or town. It has the following three categories: (1) sub-district municipalities; (2) district municipalities; and (3) city municipalities, depending on the population, civility, and development of that particular area. Municipalities are set up to manage and provide basic infrastructure for people in local areas; they permeate the daily lives of people, from birth to death. In theory, a municipality is autonomous. Municipal staff and the permanent secretary function as local government servants, carrying out their duties under the supervision of the municipal council, which is directly elected by the people.

3) The Special Administration of Bangkok; the Bangkok Metropolitan Administration divides its administration into districts and sub-districts. The Bangkok Administration Council functions as the legislative body; the governor of Bangkok is the head of the administrative body. The governor and members of the Bangkok Administration Council are elected by the people. Council members serve a term of 4 years.

4) The special administration of Pattaya includes the city council as the legislative branch, which consists of 24 elected members. The mayor of Pattaya is elected by the people and serves as the head of the executive branch.

5) The Sub-District Administration Organization is a local administrative organization under the Councils and Sub-district Administration Organization Act BE 2537, functioning as a local administrative organization at the sub-district level. This administrative unit is very close to the people in a community. A Sub-district Administration Organization developed from a sub-district Council with income up to a certain level. It is established to manage public services at the local level, villages, and sub-districts, as it is impractical for the government to administer the over 70,000 villages in the country.

\section{RESULTS}

The characteristics of the sampling group are as follows. 1) Sex: The sampling group consists of 109 males (85.16\%) and 19 females (14.84\%). 2) Age: There were 81 participants ages 41-50 (67.97\%), 30 were over 50 $(23.44 \%)$, and 1 was in the $30-40(0.78 \%)$ age group. 3) Years of experience: 110 participants $(85.94 \%)$ had less than 5 years experience and $18(14.06 \%)$ had 6-10 years experience. 3) Career position of sampling group: 78 participants were presidents of local administration organizations (60.94\%) and 50 were vice-presidents (39.06\%). 4) Type of organization: 106 represented sub-district administration organizations (82.81\%), 19 from sub-district municipalities (14.84\%), 2 from provincial municipalities (1.56\%), and 1 from a provincial administration organization (0.78\%). 5) Department: 32 participants worked in human resource departments (25.0\%), and 96 did not work in a human resource department $(75.0 \%)$.

The most important expectations of local administrative duties of HR executive officers from top-level management are as follows: 1) determining the staffing needs of the organization; 2) calculating staff salary; 3 ) handling suggestions from staff; 4) managing staff benefits; 5) conducting orientation for new staff; 6) training 
staff; 7) recording employees' time in-out; 8) drafting memos or reports for the chief executive; 9) assessing staff performance; 10) creating job descriptions; 11) advising staff about general topics; 12) liaising between administrators and staff; and 13) developing employee work performance.

The first hypothesis testing shows that top-level management at various-sized local administrative offices has the same expectations of the characteristics of human resource executive officers. The second hypothesis testing shows that top-level management at various-sized local administrative offices has the same expectations about the capabilities and efficiency of human resource executive officers.

\section{The study of the expectations of the capabilities and efficiency of human resource executive officers in top-level management of local administrative organizations.}

The research found that chief executives from various-sized local organizations expect the same roles from their human resource administrators. Today, human resources are a key factor in competing inside and outside organizations. Moreover, staff quality is another factor that boosts the organization. These changes are caused by the dynamic change in socio-economic aspects and technology, which continues to upgrade rapidly. This is why human resources have to be developed continually. Human resource administration is the key factor in the strategic plan for an organization. An organization will decrease the costs efficiency if it has enough quality staff. A ministry of commerce's study reveals that most problems that occur in small- and middle-sized organizations stem from the lack of skill and quality in their staff, high hiring costs, lack of operation staff, changing staff job descriptions, and staff inactivity. Small- and middle-sized organizations need to pay more attention to human resources and expectations to solve these problems.

The study found that chief executives in different sizes organizations expect human resource experts to be leaders of change, participate in strategic planning, and administrative development. It found that chief executives from different sized organizations expectations are similar in the top tier of human resource responsibilities, with little differences in the second, third, and fourth ranks. Chief executives want their human resource experts to develop staff loyalty to the organization. The staff should be loyal to the organization and happy to work together. Loyal employees tend to work for organizations for longer periods than non-loyal employees.

Moreover, Naksuprangsi (1997) shows that human resource administrators have to find a direction to upgrade staff performance and be the representative of the staff to propose their comments or suggestions to chief executives. Conner and Ulrich's (1996) study, which focuses on human resource administrators' competency, surveyed 256 human resource administrators from large- and middle-sized companies. They found that most human resource administrators are specialists in management and personal affairs. However, they should develop their skills and knowledge in other areas to increase performance and conform to the company's direction. Chief executives expect human resource managers to perform other roles. In addition, Ulrich and Lake (1997) explain that human resource departments should divide their time in the following manner: planning, 25\%, counseling and developing, $50 \%$, and daily administration work, $25 \%$. This differs from previous expectations, which were as follows: $65 \%$ counseling, $25 \%$ developing, and $10 \%$ planning.

The duties of HR departments explored in this study are as follows: new concepts for human resource executives in Thailand, the roles of stakeholders, planning, and leading change. Most chief executives do not highlight these roles; instead, they concentrate on the role of personal experts because it is a main function in the present day. Furthermore, the role of administration experts is classified as the daily work that human resource departments have to do. Overall, the chief executive still gives precedence to this department and believes that this department will help the organization perform well.

Researcher found that that the chief executives from various sized local organizations have the same expectations about the capabilities and efficiency of human resource executive officers ( $\mathrm{p}<0.05)$; that is, they expect the following 3 capabilities: knowledge, skill and ability, and psychological features. On average, this study found that the chief executive expects human resource executive officer's to perform the following functions: 
1) Human resource administrators should have knowledge of management, labor laws, organizational development, organizational behavior, and IT systems. The averages are 4.68, 4.41, 4.37, 4.30, and 4.22 respectively.

The first five capabilities of knowledge that the chief executive expects human resource executive officers to possess are as follows: 1) recruiting suitable staff; 2) managing staff discipline; 3) conforming to labor laws; 4) managing the health and safety of staff; and 5) creating memos and reports for chief executives. In other words, human resource administrators have to have these capabilities for organization to be successful.

2) Human resource executive officers must have the following skills and abilities: teamwork, coordination, persuasion, administrative, and conflict resolution. The averages are 4.69, 4.63, 4.56, 4.52, and 4.51 respectively.

Due to the expectation of the chief executives, who concentrate on human resource experts' skill, human resource administrators have to continuously coordinate with staff and other departments in the organization to foster harmony and consolidate the organization. This is why human resource administrators have to possess the above five skills.

3) The psychological characteristics of human resource executive officers must as follows: responsibility, loyalty, secret keeping, judgment, and neutrality. The averages are $4.74,4.69,4.66$, and 4.62 respectively. Moreover, leadership, reliability, vision, and punctuality have same average, 4.58 .

2. To explore the guidelines for the development of the capabilities and efficiency of human resource executive officers at local administrative organizations.

In this study, the researcher used the focus group technique by inviting 5 experts to participate in a discussion about how to development the capabilities and efficiency of human resource executive officers at local administrative organizations. The names of the experts are as follows:

1) Assistant Professor Teerawat Purateeranrath, Ph.D.

Faculty of Management Science, Surindra Rajabhat University, Thailand.

2) Mr.Thongphon Promsaka Na Sakolnakorn, Ph.D.

Faculty of Liberal Arts, Prince of Songkla University Hat Yai Campus, Thailand.

3) Mr.Chalongchai Mankhoksoong, Ph.D.

Faculty of Liberal Arts and Management Science,

Kasetsart University Sakon Nakhon Province Campus, Thailand.

4) Mr.Kritayut Pibool, Ph.D.

Cherngtalay sub-district administrative organization, Phuket, Thailand.

5) Mr.Weerakul Chaiphar, M.Ed.

Faculty of Humanities and Social Science, Khon Kaen University, Thailand.

From the discussion of experts, the researcher can conclude that HR executive officers must efficient in the following capabilities:

1) Human resource executive officers must understand the organizational environment. They have to study and analyze the organization and its strategy, which is connect to the factors outside of the organization, such as same as issuing objectives, planning, and knowing the SWOT technique to analyze the organization. They must know how to lead the organization to success and become acquainted with the management in the organization. In addition, they must assess the effects of their role on the organization. Moreover, human resource administrators must work as a team with the chief executive to create a new vision, mission, and strategy.

2) Human resource executive officers have to change the paradigm and work culture in the organization by using development devices such as a Balanced Scorecard, Competency Base, Performance Management System, Talent Management, and Organizational Design. 
3) Human resource executive officers have to be leaders. This skill is very important for communication, reliability, professionalism, social adaptation, relationships, activities, and knowing how to adapt to the organization.

4) Human resource executive officers must be the mediator between the organization and staff (HR Strategic Partner). Human resource administrators have to coordinate staff to foster an efficient, harmonious working environment. They must work to discovers and solve problems before it affects company performance.

5) Human resource executive officers must function as an HR expert. Human resource executive officers are strategic partners; they have to create human resource strategies and coordinate with other departments to recruit suitable resources for the organization. They need to understand the system and know the factors that develop an organization, especially in the human resource category. For instant, they must recruit new outstanding staff to develop the organization and use suitable devices to boost the organization.

\section{CONCLUSION}

The researcher concludes that knowing the expectations of chief executives for human resource executive officers is very useful in developing self performance and conforming to the organizational direction. In addition, the organization can adapt the results of this study to recruit suitable staff to work in their human resource management department by considering mission, role, capabilities, and efficiency. Finally, the HR executive officer must act as follows: 1) know the business orientation; 2) act as a change agent; 3) be a leader; 4) function as an advocate; and 5) function as an HR expert.

\section{SUGGESION FOR THE FUTURE RESEARCH}

1. Since this study focused only on Petchabun province, exploring areas outside of Petchabun would produce more beneficial results.

2. Additional research should study the comparison between the expectations of chief executives and human resource operations in the organization to evaluate human resource administrator's capabilities and efficiency and develop and guide human resource departments.

\section{ACKNOWLEDGEMENT}

The author would like to thank Dr. Thongphon Promsaka Na Sakolnakorn, Faculty of Liberal Arts, Prince of Songkla University Hat Yai Campus, Thailand, for suggestions and recommendation on this research study

\section{AUTHOR INFORMATION}

Dr. Sombut Boonleaing is a Dean of Faculty of Humanities and Social Science at Phetchabun Rajabhat University, Thailand. He received his Doctorate degree in public administration from Valaya Alongkorn Rajabhat University, Thailand. He is a specialist in the management of public organizations, human resource management, etc.

\section{REFERENCES}

1. Chareonmuan, T. 1997. Nueng Roi Pee Karn Pokkrong Thongthin Thai (A Hundred Years of Thai Local Government). Bangkok: Kobfai.

2. Conner, J. \& Ulrich, D. 1996. Human resource roles: Creating value, not rhetoric. Human Resource Planning, 19 (3), 38-47.

3. Keawying, K. 1991. Human Resource Management. $2^{\text {nd }}$ edition, Khon Kaen: Klangnanawittaya.

4. Lee, J.S. and Hsin, P.L. 2004. Employee Training and Human Capital in Taiwan. Journal of World Business, 39, 362-376.

5. Mutebi, Alex M. 2004. Recentralising while Decentralising: Centre-Local Relations and "CEO" Governors in Thailand. The Asia Pacific Journal of Public Administration, 26 (1), 33-35

6. Nagai, F., Mektrairat, N. \& Funatsu, T. 2008. Local Government in Thailand: Analysis of the Local Administrative Organization Survey. Research paper No. 147. Japan: Institute of Developing Economies. 
7. Naksuprangsi, A. 1997. The Organizational Committment of Hotel staff in Bangkok. (Master Thesis in LAbour and Welfare Development).Bangkok: The Graduate School, Thammasat University. (in Thai).

8. Nelson, Michael H. 2000. Local Government Reform in Thailand: With Some Comparative Perspectives. Nonthaburi: Center for the Study of Thai Politics and Democracy, King Prachadhipok's Institute.

10. Promsaka Na Sakolnakorn T, Aim-Im-Tham S, Khamanarong S. 2009. Management Strategy for Administration of Textile Industries in Developing Country: Case Study Thailand. Journal of Business Case Studies. 5(3), 37-44.

11. Ulrich, D., Losey. M.R. \& Lake. G. 1997. Tomorrow's HR Management. New York : John Wiley \& Sons, Inc.

12. Winotapan, P. 2009. Problem of Human Resource Management. Retrieved November 28, 2009, from, http://guru.google.co.th/guru/thread?tid=745fba72311b7afc. 
NOTES 